Kane, M. E., T.J. Sheehan, and F.H. Ferwerda. 1988b. In vitro growth of American Lotus embryos. HortScience 23:611-613.

Kane, M.E. and L.S. Albert. 1989. Comparative shoot and root regeneration from juvenile and adult aerial leaf explants of Variable-leaf Milfoil. J. Aquatic Plant Mgt. 27:1-10.

Linsmaier, E.M. and F. Skoog. 1965. Organic growth factor requirements of tobacco tissue cultures. Physiol. Plant. 18:100-127.

Rao, S. and H.Y. Mohan Ram. 1981. Regeneration of whole plants from cultured root tips of Limnophila indica. Can. J. Bet. 59:969-973.

Rataj, R. and T.J. Horeman. 1977. Aquarium plants. T. F. H., Neptune City, N.J.

SAS Institute, Inc. 1985. SAS user's guide: Sta- tistics. SAS Institute, Inc., Cary, N.C

Staritski, G. 1977. Die vitrokultur von Cryptocoryne. Aqua-Planta 1:3-6.

Urea, M.C. and H.Y. Mohan Ram. 1972. In vitro culture of Vallisneria spiralis. Phytomorphology 22:121-124.

Windelov, H. 1987. Aquarium plants. T.F.H Neptune City, N.J.

\section{Floral Supplier Service Levels to Retail Florist and Mass Market Customers}

\author{
Thomas L. Prince ${ }^{1}$, Harry K. Tayama ${ }^{2}$, and John R. Grabner, Jr. ${ }^{3}$ \\ Department of Horticulture, Ohio Agricultural Research and \\ Development Center, The Ohio State University, Columbus, OH 43210
}

Additional index word. flower, marketing, distribution channel, survey

\begin{abstract}
A survey analysis of retail florists in the Midwestern United States and floral mass marketers, nationally, profiled the level of service provided by their primary floral suppliers on 10 service characteristics. There is substantial variability in service levels provided to retail florists and mass marketers by suppliers. The greatest variability in service levels was for services relative to maintenance of product quality, product availability, communications/order information, product discounts, and product labeling. Retail florists perceived higher levels of service relative to delivery speed and order/delivery reliability than mass marketers. Mass marketers perceived higher levels of service from suppliers relative to communications/order information and product labeling, compared to retail florists. The service profiles provide floral suppliers management information for the development of service programs targeted for specific customer segments.
\end{abstract}

In the highly competitive and international business climate of the floriculture industry, managers have realized the importance of improving product quality to remain competitive. However, as the U.S. economy evolves from a production orientation to one of service (Cowell, 1984), management of many businesses is viewing improvements to service as a competitive strategy in the global marketplace (Peters and Waterman, 1982; Garvin, 1983; Takeuchi and Quelch, 1983; Heskett, 1987; Lalonde et al., 1988).

A method of incorporating service as a strategic element within a business enterprise is for management to plan and develop a

Received for publication 3 Apr. 1989. From a dissertation submitted by T.L.P. in partial fulfillment of the requirements for the $\mathrm{PhD}$. Salaries and research support provided by State and Federal Funds appropriated to the Ohio Agricultural Research and Development Center, The Ohio State Univ. Approved for publication as manuscript no. 67-89 of the Ohio Agricultural Research and Development Center, Wooster, OH 44691. The cost of publishing this paper was defrayed in part by the payment of page charges. Under postal regulations, this paper therefore must be hereby marked advertisement solely to indicate this fact.

'Postdoctoral Fellow.

${ }^{2}$ Professor of Horticulture.

${ }^{3}$ Associate Professor, Faculty of Marketing, College of Business, The Ohio State Univ., 1775 College Rd., Columbus, OH 43210. customer service program (Heskett, 1971; Prince et al., 1989). Customer service comprises, in addition to the product, activities and performances provided by a supplier to a customer, with the purpose of gaining repeat sales (Hopkins and Bailey, 1970). Customer service forms the interface between sellers and buyers in the distribution channel and forms the basis for market transactions and distribution strategy (LaLonde, 1985). In the floriculture industry, services are important, as they comprise a major share of supplier maintenance of product quality. marketers using $x^{2}$ test. the costs of marketing floral products (Goodrich, 1980; Sullivan et al., 1980).

For floral suppliers to derive the benefits of customer service, information relative to the levels of service currently provided by suppliers to their customers is needed. Development of this management information would provide floral suppliers with benchmark statistics relative to the competitive service levels within the industry. Furthermore, such industry statistics could be used by suppliers to develop target service levels or service standards when implementing a customer service program.

The survey. The research methodology was conducted as described by Prince (1989). Perceptions of suppliers' service performance were obtained from the buyers' perspective (retail florists and mass marketers), as advocated by LaLonde et al. (1988). The retail florist population comprised full-service florist shops in the states of Ohio, Indiana, Illinois, Michigan, Minnesota, Wisconsin, Iowa, Missouri, North Dakota, South Dakota, Nebraska, and Kansas. The mass-market population included supermarket chains, both cooperative organizations and independent food grocers, and nonfood mass merchandisers throughout the United States.

A random sample of firms from each population was selected and mailed questionnaires relative to services provided by suppliers. The floral buyer of each firm rated its primary supplier on the level of service provided for 10 service characteristics: supplier maintenance of product quality, order/ delivery reliability, delivery speed, product availability, order/delivery flexibility, response to problems, accessibility, commu-

Table 1. Distribution of retail florists (RF) and mass marketers (MM) reporting service levels for

\begin{tabular}{|c|c|c|c|c|c|c|}
\hline \multirow[b]{2}{*}{ Question description } & \multirow[b]{2}{*}{ Sample } & \multicolumn{5}{|c|}{ Service levels ${ }^{z, y}$} \\
\hline & & Under $80 \%$ & $80 \%-89 \%$ & $90 \%-94 \%$ & $95 \%-99 \%$ & $100 \%$ \\
\hline $\begin{array}{l}\text { Deliveries filled with } \\
\text { the quality of floral } \\
\text { product expected }\end{array}$ & $\begin{array}{l}\mathrm{RF} \\
\mathrm{MM}\end{array}$ & $\begin{array}{l}19 \\
16\end{array}$ & $\begin{array}{l}\text { Percent } \\
11 \\
8\end{array}$ & $\begin{array}{l}\text { age of firm } \\
28 \\
21\end{array}$ & $\begin{array}{l}39 \\
52\end{array}$ & $\begin{array}{l}3 \\
3\end{array}$ \\
\hline $\begin{array}{l}\text { Deliveries without } \\
\text { damage due to improper } \\
\text { packaging or shipping }\end{array}$ & $\begin{array}{l}\mathrm{RF} \\
\mathrm{MM}\end{array}$ & $\begin{array}{l}14 \\
13\end{array}$ & $\begin{array}{l}3 \\
5\end{array}$ & $\begin{array}{l}11 \\
11\end{array}$ & $\begin{array}{c}=0.57 \\
55 \\
50\end{array}$ & $\begin{array}{l}17 \\
21\end{array}$ \\
\hline $\begin{array}{l}\text { Floral product purchases } \\
\text { that are suitable for use }\end{array}$ & $\begin{array}{l}\mathrm{RF} \\
\mathrm{MM}\end{array}$ & $\begin{array}{l}12 \\
13\end{array}$ & $\begin{array}{l}2 \\
3\end{array}$ & $\begin{array}{r}11 \\
3\end{array}$ & $\begin{array}{c}=0.93 \\
65 \\
55 \\
=0.02\end{array}$ & $\begin{array}{l}10 \\
26\end{array}$ \\
\hline
\end{tabular}

${ }^{2}$ Seven-point scale collapsed into five categories; RF, $\mathrm{n}=502 ; \mathrm{MM}, \mathrm{n}=38$.

${ }^{\prime} P$ indicates significance of differences in percentage distributions between retail florists and mass 
Table 2. Distribution of retail florists (RF) and mass marketers (MM) reporting service levels for supplier order/delivery reliability and delivery speed.

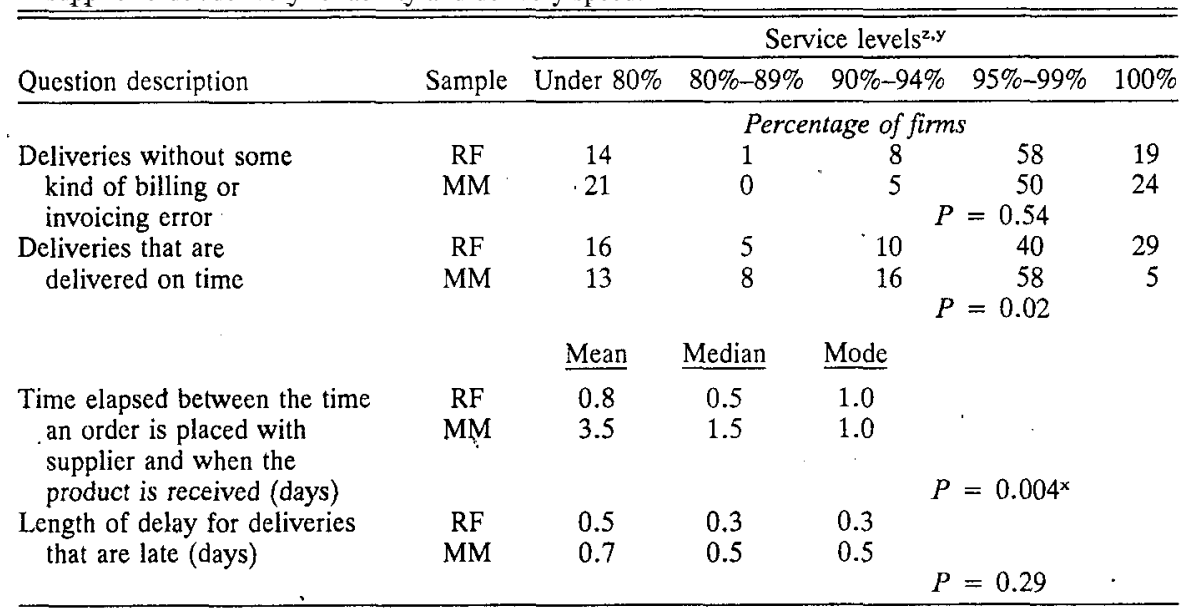

${ }^{2}$ Seven-point scale collapsed into five categories; RF, $n=502 ; M M, n=38$.

${ }^{y} P$ indicates significance of differences in percentage distributionsbetween retail florists and mass marketers using $x^{2}$ test.

${ }^{x} P$ indicates significance of differences in means between retail florists and mass marketers using $t$ test.

Table 3. Distribution of retail florists (RF) and mass marketers (MM) reporting service levels for supplier product availability.

\begin{tabular}{|c|c|c|c|c|c|c|}
\hline \multirow[b]{2}{*}{ Question description } & \multirow[b]{2}{*}{ Sample } & \multicolumn{5}{|c|}{ Service levels ${ }^{z, y}$} \\
\hline & & Under $80 \%$ & $80 \%-89 \%$ & $90 \%-94 \%$ & $95 \%-99 \%$ & $100 \%$ \\
\hline & & \multicolumn{5}{|c|}{ Percentage of firms } \\
\hline Deliveries filled with & $\mathrm{RF}$ & 12 & 4 & 10 & 55 & 19 \\
\hline $\begin{array}{l}\text { the floral products } \\
\text { ordered }\end{array}$ & MM & 11 & 3 & 18 & $P=0.30$ & 26 \\
\hline Requests accommodated & $\mathrm{RF}$ & 18 & 7 & 12 & 48 & 15 \\
\hline $\begin{array}{l}\text { for specific or unusual } \\
\text { floral product }\end{array}$ & MM & 10 & 5 & 11 & $\begin{array}{c}45 \\
P=0.21\end{array}$ & 29 \\
\hline Deliveries that do not & $\mathrm{RF}$ & 12 & -2 & 4 & 53 & 29 \\
\hline $\begin{array}{l}\text { involve a floral product } \\
\text { substituted for an } \\
\text { unavailable product }\end{array}$ & MM & 11 & 0 & 8 & $\begin{array}{c}42 \\
P=0.35\end{array}$ & 39 \\
\hline
\end{tabular}

${ }^{2}$ Seven-point scale collapsed into five categories; RF, $\mathrm{n}=502 ; \mathrm{MM}, \mathrm{n}=38$.

" $P$ indicates significance of differences in percentage distributions between retail florists and mass marketers using $x^{2}$ test.

Table 4. Descriptive statistics for retail florists (RF) and mass marketers (MM) reporting service levels for order/delivery flexibility and response to problems.

\begin{tabular}{|c|c|c|c|c|c|c|}
\hline \multirow[b]{2}{*}{ Question description } & \multirow[b]{2}{*}{ Sample } & \multicolumn{5}{|c|}{ Service levels ${ }^{\mathbf{z}, \mathbf{y}}$} \\
\hline & & Under $80 \%$ & $80 \%-89 \%$ & $90 \%-94 \%$ & $95 \%-99 \%$ & $100 \%$ \\
\hline & & \multicolumn{5}{|c|}{ Percentage of firms } \\
\hline Requests accommodated for & $\mathrm{RF}$ & 15 & 2 & 5 & 35 & 42 \\
\hline last-minute changes in delivery & MM & 13 & 3 & 8 & $\begin{array}{c}47 \\
P=0.44\end{array}$ & 29 \\
\hline \multirow{3}{*}{$\begin{array}{l}\text { Problems, such as a } \\
\text { mistake in delivery, that are } \\
\text { resolved satisfactorily }\end{array}$} & RF & 12 & 1 & 2 & 24 & 61 \\
\hline & MM & 13 & 0 & 5 & $\begin{array}{c}16 \\
P=0.54\end{array}$ & 66 \\
\hline & & Mean & Median & Mode & & \\
\hline \multirow{2}{*}{$\begin{array}{l}\text { Elapsed time between the time } \\
\text { supplier is informed of an inaccurate } \\
\text { delivery and/or unacceptable product } \\
\text { and when the error is remedied (days) }\end{array}$} & $\mathrm{RF}$ & 1.3 & 1.0 & 1.0 & & \\
\hline & MM & 1.1 & 1.0 & 1.0 & $P=0.44^{\mathrm{x}}$ & \\
\hline
\end{tabular}

${ }^{2}$ Seven-point scale collapsed into five categories; RF, $\mathrm{n}=502 ; \mathrm{MM}, \mathrm{n}=38$.

" $P$ indicates significance of differences in percentage distributions between retail florists and mass marketers using $x^{2}$ test.

${ }^{x} P$ indicates significance of differences in means between retail florists and mass marketers using $t$ test.

nications/order information, product discounts, and product labeling. A description of these service activities and their importance to floral retailers can be found in Prince et al. (1990). Questionnaire format used check-off categories, primarily sevenpoint and three-point rating scales relative to the mass-market sample, 38 questionnaires were returned (29\% response rate) and all were usable for statistical analysis. The massmarket sample was smaller than the retail florist sample because a mass-market respondent may make buying decisions for several hundred stores.

The type of suppliers identified by the survey respondents comprised wholesale florists $(81 \%)$, wholesale growers $(12 \%)$, shippers $(4 \%)$, and brokers $(3 \%)$ of floricultural products. The major products marketed by these suppliers included fresh cut-flowers $(97 \%)$, fresh cut-foliage $(65 \%)$, hardgoods $(60 \%)$, flowering potted plants $(30 \%)$, and potted foliage plants (17\%).

Reliability analysis (Cronbach, 1951) and nonresponse bias tests (Miller and Smith, 1983) were conducted to ascertain survey item reliability and validity of the survey data. Test results indicated that the service measures achieved an acceptable level of reliability $(\alpha>0.60)$ and that nonresponse bias was not a serious threat to the validity of the results. Furthermore, the random sampling of firms from their respective populations allowed the generalizing of survey results to the floral mass market and Midwestern retail florist populations at large.

Service levels are defined as the percentage of the total interactions between suppliers and retailers that met the latters' expectations.

Product quality maintenance. Results revealed wide variability in the levels of product quality provided by floral suppliers (Table 1). However, these service levels were similar for retail florists and mass marketers. About $40 \%$ of retail florists and more than one-half of mass marketers reported that $95 \%$ or more of the product deliveries were filled with the quality expected. Conversely, between $15 \%$ and $20 \%$ of retail florists and mass marketers indicated much lower product quality, with $<80 \%$ of delivered product meeting the retailers' quality expectations.

About one-half of retail florists and mass marketers reported that $95 \%$ to $99 \%$ of deliveries from their primary supplier were free from packaging or shipping damage. In addition, $\approx 20 \%$ of retail florists and mass marketers reported no damage from improper product packaging or shipping.

Although some product deliveries did not meet quality expectations, many respondents, particularly mass marketers, indicated that most products were suitable for use. About one-fourth of mass marketers reported that all purchases from their supplier were suitable for use, and about one-half reported that $95 \%$ to $99 \%$ of purchases were suitable. Retail florists reported a lesser percentage of product suitable for use than mass marketers. This difference suggests that retail florists were either more discriminating on product quality than mass marketers, or that product quality was lower for retail florists than for mass marketers.

Overall, these data on product quality suggest that most delivered floral product is suitable for the retailers' use. However, to improve product quality, suppliers may need 
Table 5. Descriptive statistics for retail florists (RF) and mass marketers (MM) reporting service levels for supplier accessibility and communications/information.

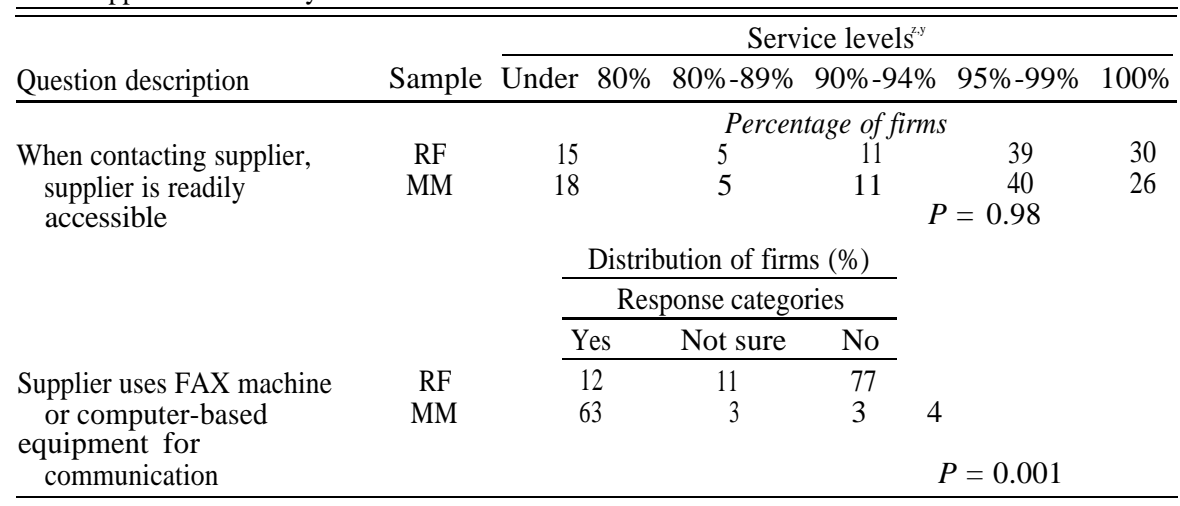

${ }^{2}$ Seven-point. scale collapsed into five categories; RF, $\mathrm{n}=502 ; \mathrm{MM}, \mathrm{n}=38$.

${ }^{\prime} P$ indicates significance of differences in percentage distributions between retail florists and mass marketers using $x^{2}$ test

Table 6. Descriptive statistics for retail florists (RF) and mass marketers (MM) reporting service levels for supplier quantity and cash payment discounts.

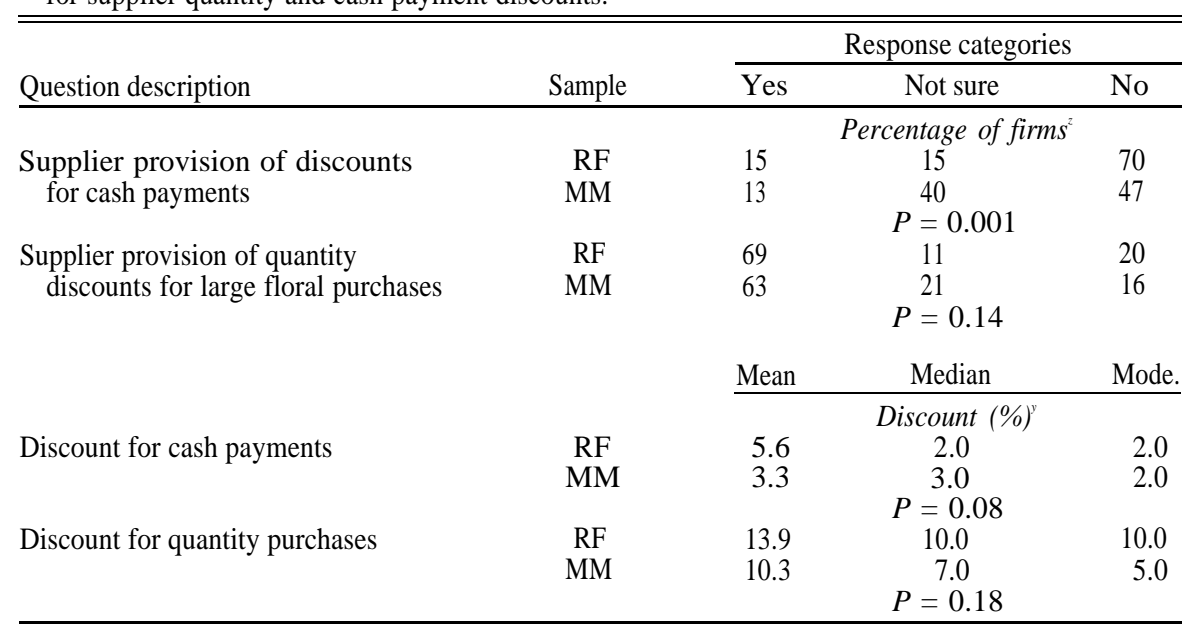

${ }^{2} P$ indicates significance of differences in percentage distributions between retail florists and mass marketers using $x^{2}$ test.

${ }^{y} P$ indicates significance of differences in means between retail florists and mass marketers using $t$ test.

Table 7. Distribution of retail florists (RF) and mass marketers (MM) reporting service levels for supplier product labeling.

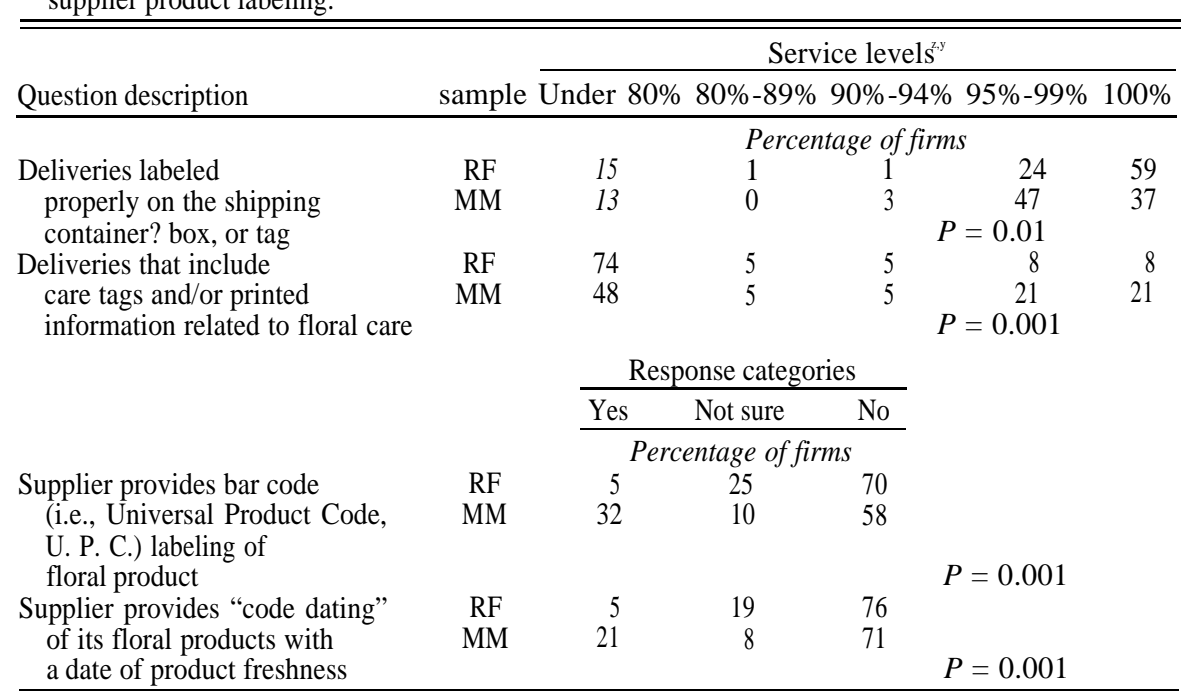

${ }^{2}$ Seven-point scale collapsed into five categories; RF, $\mathrm{n}=502 ; \mathrm{MM}, \mathrm{n}=38$.

${ }^{y} P$ indicates significance of differences in percentage distributions between retail florists and mass marketers using $x^{2}$ test.

to pay more attention to production and postproduction treatments, rather than focusing attention on packaging and shipping meth-

ods. In addition, floral suppliers should closely monitor product quality received by customers to ensure that it meets the retailers' expectations.

Delivery reliability and delivery speed. Floral retailers reported a high level of consistency in ordering/billing by their supplier, as one-fifth of retail florists and one-fourth of mass marketers reported no billing or invoicing errors by their supplier (Table 2 ). In addition, $\approx 50 \%$ of each group indicated that these errors accounted for $<5 \%$ of deliveries.

The service level data indicated that retail florists perceived higher levels of delivery reliability by their supplier than mass marketers (Table 2). Nearly $30 \%$ of retail florists reported on-time delivery, compared to only $5 \%$ for mass marketers. However, this difference in perception may be due to morestringent delivery scheduling standards of mass marketers compared to retail florists.

Retail florists reported that they receive better than a 1-day turnaround time from their supplier (Table 2). This response time is from the time they placed an order to the time they received the product. In contrast, mass marketers received a 3.5-day turnaround time from their primary supplier. For deliveries not on time, the average delay was about one-half day for retail florists and mass marketers, with most retail florists reporting threetenths of a day delay in delivery. The duration of these delays varied substantially, ranging from $\approx 30 \mathrm{~min}$ to 7 days. Overall, these data on ordering/delivery suggest that suppliers provided excellent service in ordertaking" and processing reliability, but provided less consistency on delivery, especially for mass-market retailers.

Product availability. About $75 \%$ of retail florists and $70 \%$ of mass marketers reported an order fill rate of $95 \%$ or higher (Table 3). According to the responses, $15 \%$ of retail florists and twice as many mass marketers reported all requests for specific or unusual floral products were accommodated by their supplier; about one-fifth of retail florists but only $10 \%$ of mass marketers reported a lower level of service, as $<80 \%$ of requests for specific or unusual floral products by these retailers were accommodated by their supplier (Table 3). Most suppliers do not substitute other types of product for unavailable product, as $>80 \%$ of respondents reported that $95 \%$ or more of product deliveries did not involve product substitutes (Table 3). These results indicate that, while retailers usually receive the products ordered, many requests for unique or unusual products are not accommodated and product substitutions for unavailable products are not employed to any great extent.

Order/delivery flexibility and responsiveness. More than $75 \%$ of retail florists and mass marketers indicated that their primary supplier accommodated $95 \%$ or more of requests for last-minute changes in delivery (Table 4). In addition, $>80 \%$ of the respondents reported that, when problems in delivery occur, $95 \%$ or more are solved to the retailer's satisfaction.. Elapsed time for a supplier to remedy a problem, however, varied widely, ranging from a few minutes to 30 days, but averaged slightly more than a 
day. These results revealed that most suppliers provided a high level of flexibility and responsiveness in product delivery for their customers.

Accessibility and communications/order information. About $30 \%$ of respondents indicated that their primary supplier was always readily accessible, and $\approx 40 \%$ indicated their supplier was accessible $95 \%$ to $99 \%$ of the time (Table 5). These data reveal that a large segment of floral suppliers provided high levels of accessibility and convenience for their customers.

The speed and reliability of communication between supplier and customer is an element of service that can be developed through the adoption, of appropriate communications technology. The suppliers' usage of communication/order information technology to communicate with their customers varied between respondent groups (Table 5), as mass marketers perceived higher levels of this service. Nearly two-thirds of mass marketers reported that their primary supplier used a facsimile (FAX) machine or other computerbased technology for communication, whereas only one-eighth of retail florists indicated that their supplier used this technology. Since the implementation of this technology requires adoption by both supplier and customer, these statistics suggest that the majority of retail florists have not adopted innovated technologies that may aid communication with suppliers.

Cash and quantity discounts. About $15 \%$ of retail florists and mass marketers reported that their primary supplier provided a discount for early cash payments (Table 6). For these respondents, this early payment discount averaged between $3 \%$ to $6 \%$ of sales, with most respondents reporting a $2 \%$ cash discount.

Although $15 \%$ or fewer of respondents reported a provision of cash discounts, $>60 \%$ indicated that their primary supplier offered discounts for purchasing in large quantities (Table 6). Most retail florists and mass marketers cited a discount of $10 \%$ and $5 \%$, respectively, but the discounts ranged-from $1 \%$ to $49 \%$. These discounts were heavily dependent on the quantity purchased, the variety of floral product purchased, and the season of the year. These results suggest that, while suppliers have readily offered discounts to their customers for quantity purchases, they have restricted discounts for early payments.

Product labeling. About $60 \%$ of retail florists and nearly $40 \%$ of mass marketers reported that all deliveries from their primary supplier were labeled properly, while about one-fourth of retail florists and about onehalf of mass marketers reported that up to $5 \%$ of deliveries were labeled improperly on the shipping container, box, or tag (Table 7). In addition, nearly three-fourths of retail florists and about one-half of mass marketers reported that fewer than $80 \%$ of deliveries included "care tags" or printed information related to product care. Many suppliers apparently do not provide product care and handling information at the point of delivery for all products.

The service level data suggested that mass marketers received higher levels of labeling services from their suppliers than retail florists (Table 7). Very few retail florists reported that their supplier offered bar code labeling technology, whereas one-third of mass marketers indicated that suppliers offered this technology. In addition, only 5\% of retail florists, but four times as many mass marketers, indicated that their supplier used code dating, an indicator of product freshness. Overall, these data revealed the low adoption rate of advanced labeling services by floral suppliers.

"Implications for management. A review of the results suggests that suppliers provided high levels of service relative to order/delivery reliability, delivery speed, order/delivery flexibility, response to problems, and accessibility. However, there is substantial variability in supplier services relative to maintenance of product quality, product availability, communications/order information, product discounts, and product labeling. This variability suggests that floral suppliers may not fully understand the service requirements of their customers. However, this variability in service also identifies market opportunities for suppliers developing customer service programs.

A comparison of the two customer segments revealed that retail florists perceived higher levels of service from their suppliers relative to order/delivery reliability and delivery speed than mass marketers. Mass marketers perceived higher levels of service from their suppliers relative to communications/ order information and product labeling than retail florists. These differences in service levels between both groups suggest that the service requirements for each group may be different, thus requiring the establishment of separate service standards for each segment when developing a customer service program.

Although the implementation of a customer service program requires suppliers to estimate costs and benefits for a given service level, this research assists suppliers in developing such programs. The service profiles provide benchmark statistics for 10 service activities in floral distribution. These service profiles may be used by suppliers in the establishment of service standards for their customers. Furthermore, the segmented service profiles highlight the strengths and weaknesses in customer service for florist and mass-market groups and may aid suppliers in developing effective service programs targeted for specific customer segments.

\section{Literature Cited}

Cowell, D.W. 1984. The marketing of services. CAM Foundation, London.

Cox, E. 1980. The optimal number of response alternatives for a scale: A review. J. of Mktg. Res. 17:407-422.

Cronbach, L.J. 1951. Coefficient alpha and the internal structure of tests. Psychometrika 16:297334.

Garvin, D.A. 1983. Quality on the line. Harvard Business Rev. 61:65-73.

Goodrich, D. C., Jr. 1980. Floral marketing. Chain Store Publishing, New York.

Heskett, J.L. 1971. Controlling customer logistics service. Intl. J. of Phys. Distrib. 1: 140-145.

Heskett, J.L. 1987. Lessons in the service sector. Harvard Business Rev. 65(2):1 18-126.

Hopkins, D.S. and E.L. Bailey. 1970. Customer service: A progress report. The Conference Board, New York.

LaLonde, B.J. 1985. Customer service, p. 235256. In: J.F. Robeson (ed.). The distribution handbook. Natl. Council of Phys. Distrib. Mgt., The Free Press, New York.

LaLonde, B. J., M.C. Cooper, and T.G. Noordewier. 1988. Customer service: A management perspective. Council of Logistics Mgt., Oak Brook, 111.

Miller, L.E. and K.L. Smith. 1983. Handling nonresponse issues. J. of Ext. 21(5):45-50

Peters, J.T. and W.H. Waterman. 1982. In search of excellence. Harper \& Row, New York.

Prince, T.L. 1989. Customer service of floriculture suppliers in the Midwestern floral distribution channels: Its relationship to retailer satisfaction and purchasing intention. PhD Diss., The Ohio State Univ., Columbus.

Prince, T. L., H.K. Tayama, and J.R. Grabner, Jr. 1989. Developing an effective customer service program, part I: Defining customer service. Ohio Florists' Assn. Bul. 713: 1-4.

Prince, T. L., H.K. Tayama, and J.R. Grabner, Jr. 1990. Supplier services and their importance to floral retailers in the midwestem United States. HortScience 25:356-358.

Sullivan, G. H., J.L. Robertson, and G.L. Staby. 1980. Management for retail florists. Freeman, San Francisco.

Takeuchi, H. and J.A. Quelch. 1983. Quality is more than making a good product. Harvard Business Rev. 61(4):139-145. 